\title{
Microorganisms facilitate uptake of dissolved organic nitrogen by seagrass leaves
}

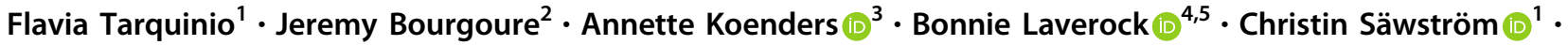 \\ Glenn A. Hyndes $\mathbb{D}^{1}$
}

Received: 31 January 2018 / Revised: 21 May 2018 / Accepted: 13 June 2018 / Published online: 5 July 2018

(c) International Society for Microbial Ecology 2018

\begin{abstract}
Microorganisms play a critical role in nitrogen cycling by mineralising dissolved organic nitrogen (DON) compounds into bioavailable inorganic forms (DIN). Although DIN is crucial for seagrass growth, the hypothesis that seagrass leaf associatedmicroorganisms could convert DON to forms available for plant uptake has never been tested. We conducted a laboratorybased experiment in which seagrass (Posidonia sinuosa) leaves were incubated with ${ }^{15} \mathrm{~N}$-amino acids (aa), with and without associated microorganisms. Samples were collected after 0.5, 2, 6 and $12 \mathrm{~h}$. Both bulk stable isotope and nanoscale secondary ion mass spectrometry (NanoSIMS) analysis showed high accumulation of ${ }^{15} \mathrm{~N}$ within seagrass leaf tissues with an associated microbiota, but not in plants devoid of microorganisms. These results significantly change our understanding of the mechanisms of seagrass nitrogen use and provide evidence that seagrass microbiota increase nitrogen availability for uptake by seagrass leaves by mineralising aa, thus enhancing growth and productivity of these important coastal ecosystems.
\end{abstract}

\section{Introduction}

Seagrass meadows are extremely productive aquatic habitats that provide important ecological functions, such as refuge and nutrient sources for a great variety of marine organisms $[1,2]$. Nitrogen $(\mathrm{N})$ is an essential element for maintaining

These authors contributed equally: Flavia Tarquinio, Jeremy Bourgoure.

Electronic supplementary material The online version of this article (https://doi.org/10.1038/s41396-018-0218-6) contains supplementary material, which is available to authorised users.

Glenn A. Hyndes

g.hyndes@ecu.edu.au

1 Centre for Marine Ecosystems Research, School of Science, Edith Cowan University, Joondalup, WA, Australia

2 Centre for Microscopy, Characterisation and Analysis, The University of Western Australia, Crawley, WA, Australia

3 Centre for Ecosystem Management, School of Science, Edith Cowan University, Joondalup, WA, Australia

4 Plant Functional Biology and Climate Change Cluster, University of Technology Sydney, Sydney, Australia

5 School of Science, Auckland University of Technology, Auckland, New Zealand seagrass growth and productivity [3, 4], with foliar uptake of $\mathrm{N}$ often contributing more of the plant total $\mathrm{N}$ requirement compared with roots (up to 74\% [5]). Although seagrass leaves preferentially uptake inorganic nitrogen (DIN [6]), paradoxically, seagrasses flourish in coastal environments characterised by scarce inorganic nutrients, but high concentrations of dissolved organic nitrogen (DON [7, 8]).

Within the marine environment, microorganisms on the surface of plants and animals can be highly abundant [9], forming functional partnerships that can play a critical role in nutrient acquisition from oligotrophic waters [10]. Seagrass leaves provide a physical substratum for a rich epiphytic community of autotrophic and heterotrophic microorganisms $[11,12]$. Surprisingly, while the contribution of the autotrophic microbiota (i.e. nitrogenfixing bacteria) to enhance seagrass $\mathrm{N}$ availability has been extensively reported [13], the significance of heterotrophic microorganisms on seagrass leaves in facilitating the plant's ability to uptake $\mathrm{N}$ from DON has been largely overlooked.

\section{Materials and methods}

Here, we tested whether seagrass microbiota, through the conversion of amino acids (aa) into bioavailable DIN, 
Fig. $1{ }^{15} \mathrm{~N}$ enrichment images of seagrass $(P$. sinuosa) leaf cells after incubation in enriched ${ }^{15} \mathrm{~N}$ aa mixture with (a-d) or without $(\mathbf{e}-\mathbf{h})$ microorganisms on their leaves. Seagrass leaves were incubated for $0.5 \mathrm{~h}(\mathbf{a}, \mathbf{e}), 2 \mathrm{~h}$ $(\mathbf{b}, \mathbf{f}), 6 \mathrm{~h}(\mathbf{c}, \mathbf{g})$ and $12 \mathrm{~h}$

$(\mathbf{d}, \mathbf{h})$. Seagrass sub-cellular compartments are reported (CW cell wall, Ch chloroplast,

Va vacuole, Cy cytosol), as well as microorganisms (M). ${ }^{15} \mathrm{~N}$ enrichment images generated from nanoSIMS collected ${ }^{12} \mathrm{C}^{14} \mathrm{~N}^{-}$and ${ }^{12} \mathrm{C}^{15} \mathrm{~N}^{-}$ion data and expressed as hue saturation intensity, where blue represents low isotopic abundance of nitrogen $\left(\delta^{15} \mathrm{~N} \% o=0\right.$; close to natural abundance) and enrichment is shown as a shift towards magenta (colour scale label in $\delta^{15} \mathrm{~N} \%$ o). The images show a ${ }^{15} \mathrm{~N}$ enrichment of seagrass cell wall at $0.5 \mathrm{~h}$ (a) and the appearance of enriched substrate within the cytosol and vacuole $(\mathbf{b}, \mathbf{c})$ and chloroplasts

(d) over time. Where

microorganisms are absent $(\mathbf{e}-\mathbf{h})$ a clear enrichment is absent. Scale bar represents $5 \mu \mathrm{m}$
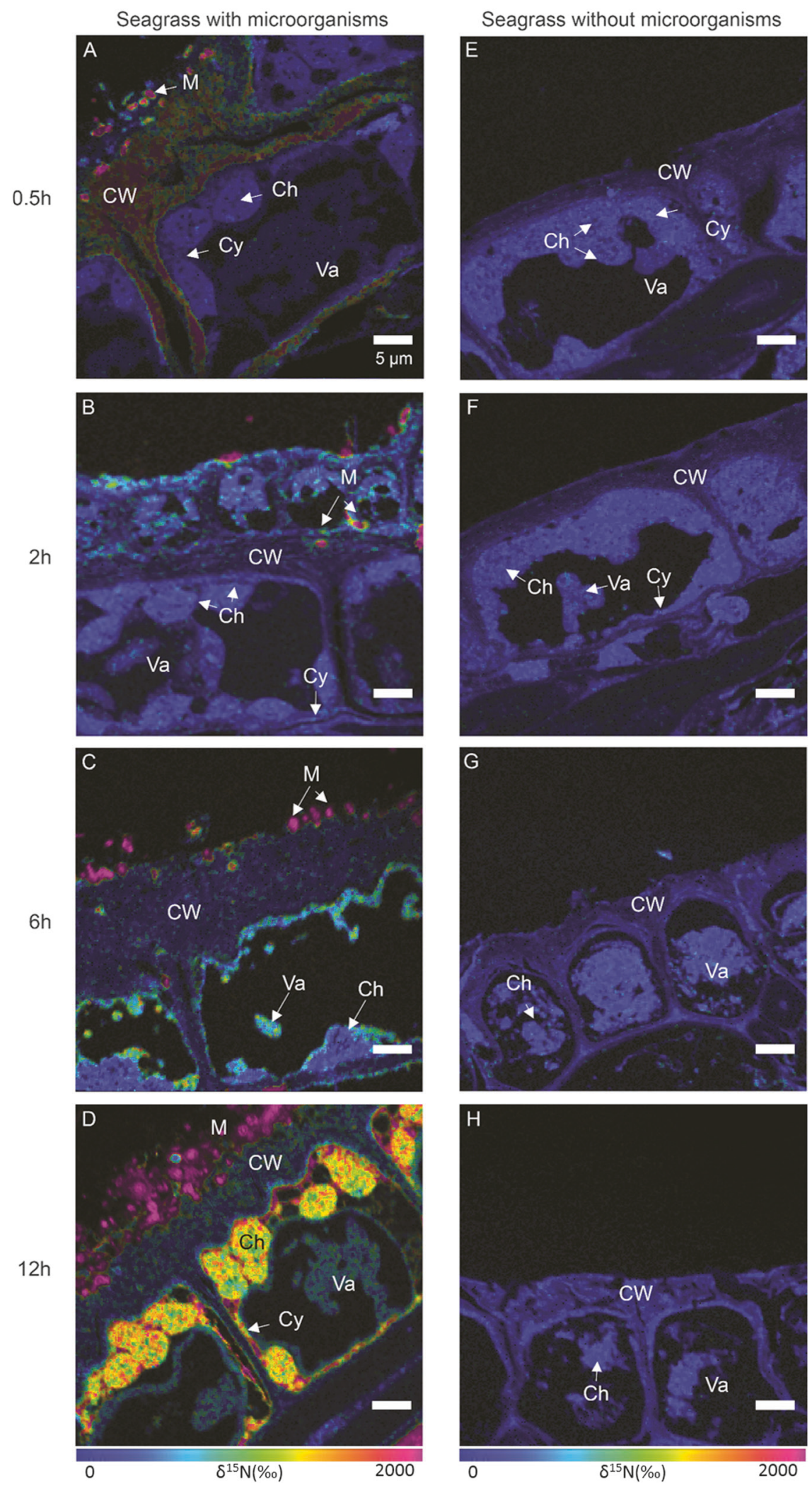

mediate the assimilation of $\mathrm{N}$ by seagrass leaves. We exposed seagrass (Posidonia sinuosa) leaves, with and without microorganisms, to ${ }^{15} \mathrm{~N}$-enriched aa $(50 \mu \mathrm{M}$ of
$98 \%{ }^{15} \mathrm{~N}$-aa; NLM-2161 Cambridge Isotope Laboratories) and ${ }^{14} \mathrm{~N}$-aa (controls; $50 \mu \mathrm{M}$ of $98 \%{ }^{14} \mathrm{~N}$-aa; ULM-2314 Cambridge Isotope Laboratories) over $12 \mathrm{~h}$. Epiphytes 


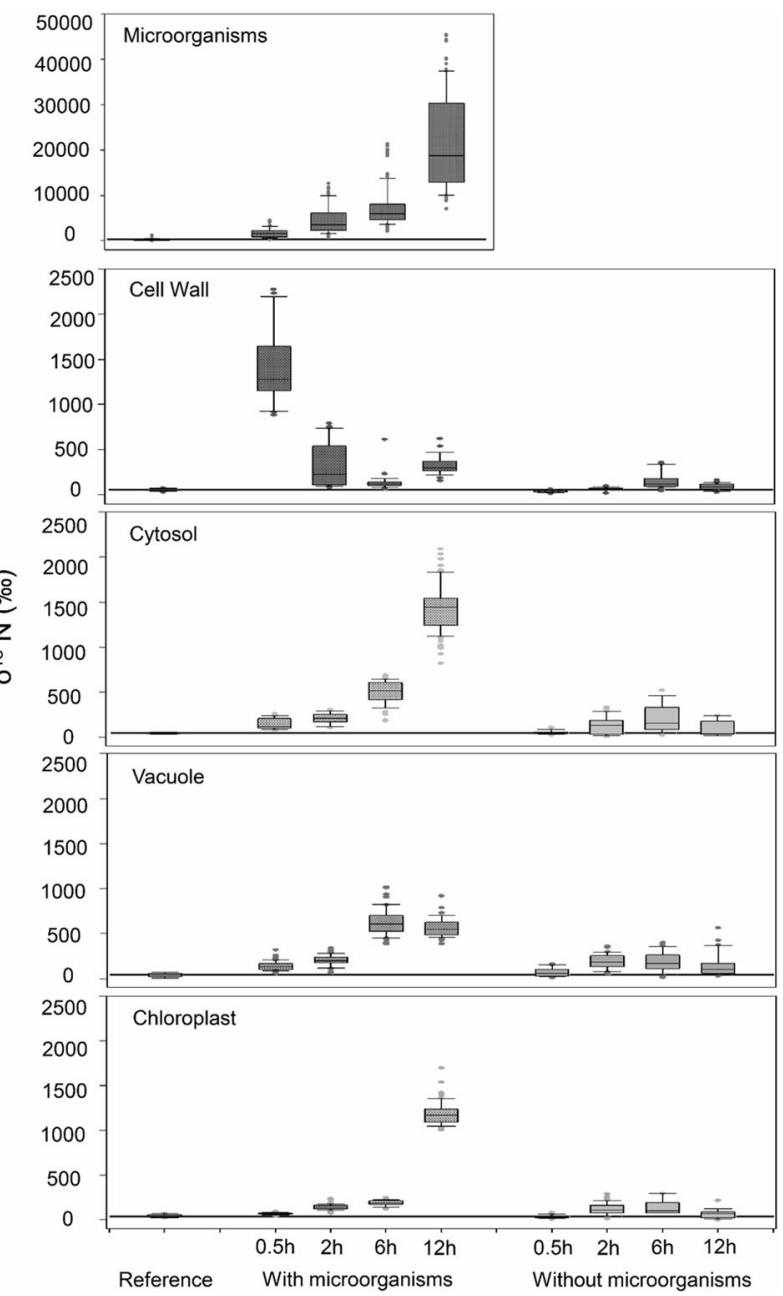

Fig. 2 Box-Whisker plots (median, interquartile range $=$ box, extremes $=$ whiskers) of ${ }^{15} \mathrm{~N}$ enrichment of identifiable microorganisms and sub-cellular seagrass components (cell wall, cytosol, vacuole and chloroplast) from nanoSIMS analysis of seagrass leaves incubated with (left) or without (right) associated microorganisms for each incubation time, up to $12 \mathrm{~h}$. Reference values (reference), representing $\delta^{15} \mathrm{~N}$ natural abundance for microorganisms and seagrass sub-cellular compartments obtained from incubation with non-enriched ${ }^{14} \mathrm{~N}$ aa, are displayed for each graph. Note the difference in $y$-axis scales between microorganisms and plant sub-cellular components

and microorganisms were removed through scraping visible leaf epiphytes using a razor blade and incubation with antibiotics, followed by examination of potential damage by transmission electron microscopy and pulse amplitude modulated (PAM) fluorometry (see Supplementary Methods including Figs. S1, S2 \& S3). ${ }^{15} \mathrm{~N}$ accumulation into seagrass leaves $(n=3$ per treatment/ control) was first measured by isotope ratio mass spectrometry (IRMS), after which a subset of samples was randomly selected and analysed by high-resolution mass spectrometry (NanoSIMS) to show ${ }^{15} \mathrm{~N}$ accumulation in microorganisms on the leaf surface and discrete subcellular components (cell wall, cytosol, vacuole and chloroplast) of seagrass leaves (see Supplementary Methods for details of techniques).

\section{Results and discussion}

Evidence that microorganisms associated with $P$. sinuosa leaves facilitate seagrass uptake of ${ }^{15} \mathrm{~N}$ derived from aa was provided by our results of bulk tissue analysis (IRMS) of seagrass leaves with and without intact microorganisms. At all times following incubation, ${ }^{15} \mathrm{~N}$ accumulation was greater in leaves with an associated microbiota compared to those where microorganisms had been removed, with levels 4.5 times higher in leaves with microorganisms by $12 \mathrm{~h}$ $(p<0.001$; Supplementary Fig. S3). However, bulk isotope measures are unable to discern specific isotope tracer accumulation points or the source of slight ${ }^{15} \mathrm{~N}$ enrichment we detected in leaves removed of microorganisms. Consequently, high-resolution secondary ion mass spectrometry (NanoSIMS) was done on representative samples to trace the uptake of ${ }^{15} \mathrm{~N}$ derived from aa at the $P$. sinuosa leaf-microbial interface.

NanoSIMS analysis of seagrass leaves with intact microorganisms clearly distinguished the associated microorganisms from seagrass cells, with resolution sufficient to differentiate the sub-cellular components of the seagrass leaf (cell wall, vacuole, cytosol and chloroplast; Supplementary Fig. S5). After $0.5 \mathrm{~h}$ incubation in ${ }^{15} \mathrm{~N}$-aa, analysis showed microorganisms on the surface of the seagrass leaf were highly enriched compared to the adjacent seagrass cells (Figs. 1 and 2). The microorganisms remained more ${ }^{15} \mathrm{~N}$ enriched than adjacent seagrass cells at each time, and their enrichment was characterised by an exponential accumulation of ${ }^{15} \mathrm{~N}$ over time (Fig. 2). By $12 \mathrm{~h}$, microorganisms were $\sim 200$ times more ${ }^{15} \mathrm{~N}$-enriched than unlabelled reference samples, indicating the efficiency of microorganisms to utilise aa through the activity of intracellular and extracellular enzymes that break down aa to produce DIN [14].

The presence of microorganisms, and their ability to mineralise aa, clearly influenced the accumulation of ${ }^{15} \mathrm{~N}$ into different components of the seagrass tissue over the experiment timescale (Figs. 1 and 2). Within $0.5 \mathrm{~h}$ of incubation, ${ }^{15} \mathrm{~N}$ was 26 times higher in the outer cell wall of epidermal cells of seagrass leaves with microorganisms present compared to those with microorganisms removed. While the mechanisms of absorption of solutes through the cuticle are not fully characterised [15], the enhanced and subsequent decreased enrichment of ${ }^{15} \mathrm{~N}$ in the cell wall (Figs. 1a-c and 2) suggests that: (i) the movement of $\mathrm{N}$ across the seagrass cuticle is a rapid process [16]; (ii) the added aa source was quickly exhausted; or less likely; and (iii) the plant is able to limit $\mathrm{N}$ uptake once it has reached substrate saturation [6]. Slight ${ }^{15} \mathrm{~N}$ accumulation was first observed in the cytosol and 
vacuole after $0.5 \mathrm{~h}$, followed by an exponential accumulation over time (Fig. 1d). The chloroplasts that proliferate at the outer edge of the seagrass epidermal cells accumulated ${ }^{15} \mathrm{~N}$ more slowly than other seagrass sub-components, and still showed increasing enrichment at the final $12 \mathrm{~h}$ sampling time. Since microbial catabolism of aa results in exuded ammonium $\left(\mathrm{NH}_{4}{ }^{+}\right.$[14]) and $\mathrm{NH}_{4}{ }^{+}$is the preferred DIN source for foliar seagrass acquisition, the microorganisms associated with seagrass above-ground tissue appear to provide a mechanism for the seagrass leaves to access $\mathrm{N}$ derived from aa. While $\mathrm{NH}_{4}{ }^{+}$is harmful to plant tissue (at concentrations as low as $25 \mu \mathrm{M}$, ambient concentration around $15 \mu \mathrm{M}$ [17]), our data show that it quickly moves to chloroplasts where it is assimilated into organic compounds, some of which are released back into the cytosol [6].

The role of microorganisms in mediating the uptake of $\mathrm{N}$ by seagrass leaves is further supported by isolated uptake of ${ }^{15} \mathrm{~N}$ by seagrass cells that were adjacent to small 'patches' of microorganisms missed in the removal process. NanoSIMS analysis, and corresponding live/dead cell counts, revealed a few examples where microorganisms were not entirely removed ( $<1 \%$ leaf surface; Supplementary Figs. S1 \& S6). In these specific areas, the few remaining microorganisms were 20 times more ${ }^{15} \mathrm{~N}$-enriched than those of unlabelled reference samples, and only seagrass cells directly adjacent to those microorganisms exhibited ${ }^{15} \mathrm{~N}$ enrichment (Supplementary Fig. S4). Overall, our results cast doubt over the ability of seagrasses to utilise DON directly as a source of essential N. Previous studies $[18,19]$ that postulated seagrass ability to directly use DON did not completely remove microorganisms from seagrass tissues prior to incubation with ${ }^{15} \mathrm{~N}$, and our findings suggest that even small numbers of microorganisms on seagrass leaves influence the uptake of $\mathrm{N}$ derived from aa.

\section{Conclusions}

In this study, we show that the association between microorganisms and the leaves of $P$. sinuos $a$ can provide an alternative source of $\mathrm{N}$ for uptake by seagrass from the abundant organic nitrogen pool. By mineralising amino acids, epiphytic microorganisms on $P$. sinuosa leaves link the nitrogen elemental cycle in seagrass meadows via heterotrophic metabolism and are likely to contribute significantly to the high productivity of seagrass meadows. Thus, the maintenance of a 'stable' partnership between seagrass leaves and its microbiota, indirectly enables the provision of the pivotal ecosystem services provided by these important, globally distributed, benthic habitats [20].

Acknowledgements The authors thank R. Bernasconi (Edith Cowan University, ECU) for her assistance with fieldwork and A. Lafratta (ECU) for assistance with the enrichment experiment. The authors thank Centre for Microscopy, Characterisation and Analysis (CMCA) at The University of Western Australia for its support offered with NanoSIMS and confocal microscope analysis. This work was supported by the School of Science (ECU), the Department of Biodiversity, Conservation and Attractions, Western Australia, and the Collaborative Research Network (CRN) comprising Edith Cowan University and The University of Western Australia.

Author contributions F.T. conducted the fieldwork and performed the $\mathrm{DO}^{15} \mathrm{~N} / \mathrm{DO}^{14} \mathrm{~N}$ enrichment experiment. J.B. and FT did epifluorescent microscopy. G.A.H. provided critical input for bulk stable isotope interpretation. F.T. and JB generated the NanoSIMS data. F.T., J.B., G.A.H. and AK interpreted the NanoSIMS data, analysed all the data and prepared figures. All authors contributed to the design of the research project, data interpretation, and manuscript production.

\section{Compliance with ethical standards}

Conflict of interest The authors declare that they have no conflict of interest.

\section{References}

1. Duarte CM, Chiscano CL. Seagrass biomass and production, a reassessment. Aquat Bot. 1999;65:159-74.

2. Heck KL, Carruthers TJ, Duarte CM, Hughes AR, Kendrick G, Orth RJ, et al. Trophic transfers from seagrass meadows subsidize diverse marine and terrestrial consumers. Ecosystems. 2008;11: 1198-210.

3. Zimmerman RC, Smith RD, Alberte RS. Is growth of eelgrass nitrogen limited? A numerical simulation of the effects of light and nitrogen on the growth dynamics of Zostera marina. Mar Ecol Prog Ser. 1987;41:167-76.

4. Williams SL. Experimantal studies of caribbean seagrass bed development. Ecol Monogr. 1990;60:449-69.

5. Alexandre A, Silva J, Bouma TJ, Santos R. Inorganic nitrogen uptake kinetics and whole-plant nitrogen budget in the seagrass Zostera noltii. J Exp Mar Biol Ecol. 2011;401:7-12.

6. Touchette BW, Burkholder JM. Review of nitrogen and phosphorus metabolism in seagrasses. J Exp Mar Biol Ecol. 2000;250: 133-67.

7. Stepanauskas R, Leonardson L, Tranvik LJ. Bioavailability of wetland-derived DON to freshwater and marine bacterioplankton. Limnol Oceanogr. 1999;44:1477-85.

8. Berman T, Bronk DA. Dissolved organic nitrogen, a dynamic participant in aquatic ecosystems. Aquat Microb Ecol. 2003;31: 279-305.

9. Flemming HC, Wingender J, Szewzyk U, Steinberg P, Rice SA, Kjelleberg S. Biofilms, an emergent form of bacterial life. Nat Rev Microbiol. 2016;14:563-75.

10. Wahl M, Goecke F, Labes A, Dobretsov S, Weinberger F. The second skin, ecological role of epibiotic biofilms on marine organisms. Front Microbiol. 2012;3:292.

11. Uku J, Björk M, Bergman B, Díez B. Characterization and comparison of prokaryotic epiphytes associated with three east African seagrasses. J Phycol. 2007;43:768-79.

12. Crump BC, Koch EW. Attached bacterial populations shared by four species of aquatic angiosperms. Appl Environ Microbiol. 2008;74:5948-57.

13. Welsh DT. Nitrogen fixation in seagrass meadows: regulation, plant-bacteria interactions and significance to primary productivity. Ecol Lett. 2000;3:58-71.

14. Chróst RJ. Environmental control of the synthesis and activity of aquatic microbial ectoenzymes. In Microbial enzymes in 
aquatic environments. New York, NY: Springer; 1991. p. 29-59.

15. Khayet M, Fernández V. Estimation of the solubility parameter of model plant surfaces and agrochemicals, a valuable tool for understanding plant surface interactions. Theor Biol Med Model. 2012;9(1):45.

16. Riederer M, Schreiber L. Waxes, the transport barriers of plant cuticles. Waxes Chem Mol Biol Funct. 1995;6:131-56.

17. Van Katwijk, MM, Vergeer, LHT, Schmitz, GHW, \& Roelofs, JGM (1997). Ammonium toxicity in eelgrass Zostera marina. Mar Ecol Prog Ser 159-73.
18. Van Engeland T, Bouma TJ, Morris EP, Brun FG, Peralta G, Lara $\mathrm{M}$, et al. Potential uptake of dissolved organic matter by seagrasses and macroalgae. Mar Ecol Prog Ser. 2011; 427:71-81.

19. Vonk JA, Middelburg JJ, Stapel J, Bouma TJ. Dissolved organic nitrogen uptake by seagrasses. Limnol Oceanogr. 2008;53: $542-8$.

20. Säwström C, Hyndes GA, Eyre BD, Huggett MJ, Fraser MW, Lavery PS, et al. Coastal connectivity and spatial subsidy from a microbial perspective. Ecol Evol. 2016;6:6662-71. 